\title{
Branding yoga The cases of lyengar Yoga, Siddha Yoga and Anusara Yoga
}

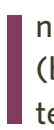
n October 1989, long-time yoga student, John Friend (b. 1959) travelled to India to study with yoga masters. First, he went to Pune for a one-month intensive postural yoga programme at the Ramamani lyengar Memorial Yoga Institute, founded by a world-famous yoga proponent, B. K. S. lyengar (b. 1918). Postural yoga (De Michelis 2005, Singleton 2010) refers to modern biomechanical systems of yoga, which are based on sequences of asana or postures that are, through pranayama or 'breathing exercises', synchronized with the breath. ${ }^{1}$ Following Friend's training in lyengar Yoga, he travelled to Ganeshpuri, India where he met Chidvilasananda (b. 1954), the current guru of Siddha Yoga, at the Gurudev Siddha Peeth ashram. ${ }^{2}$ Siddha Yoga is a

1 Focusing on English-speaking milieus beginning in the 1950s, Elizabeth De Michelis categorizes modern yoga into three types: Modern Postural Yoga, which stresses physical exercises, and Modern Meditational Yoga, which stresses concentration and meditation (De Michelis 2005: 187). These types express little concern for religious and philosophical doctrine, and instead they often stress that such aspects of yoga depend on individual experience rather than doctrinal deliberation (De Michelis 2005: 187-8). The third type, Modern Denominational Yoga, includes systems that do express concern for religious and philosophical doctrine (De Michelis 2005: 189). According to De Michelis' typology, Iyengar Yoga is an example of Modern Postural Yoga, whereas Siddha Yoga is an example of Modern Denominational Yoga. In this article, I am primarily concerned about what De Michelis would categorize as Modern Postural Yoga and Modern Denominational Yoga, but I use the less reificatory terms, postural yoga and soteriological yoga respectively.

2 Amongst disciples, Chidvilasananda is also affectionately known as Gurumayi, which means 'Guru Mother' in Marathi, or, in Sanskrit, 'one who is filled with the guru' (Durgananda 1997: note 247). An modern soteriological yoga system based on ideas and practices primarily derived from tantra. The encounter profoundly transformed Friend, and Chidvilasananda initiated him into Siddha Yoga (Williamson forthcoming).

FRIEND SPENT THE NEXT SEVEN YEARS deepening his understanding of both Iyengar Yoga and Siddha Yoga. He gained two Iyengar Yoga teaching certificates and taught Iyengar Yoga in Houston, Texas. Every summer, he travelled to Siddha Yoga's Shree Muktananda Ashram in upstate New York, where he would study for one to three months at a time.

Friend founded his own postural yoga system, Anusara Yoga, in 1997 in The Woodlands, a highend Houston suburb. Anusara Yoga quickly became one of the most popular yoga systems in the world. In a 2010 interview with a New York Times journalist, Friend made the following statement about how Anusara Yoga compares to other yoga systems: '[People know about physically-oriented yoga] but as we grow they are going to learn about Anusara. Then people can choose - either they are going to go to a fast-food joint or a fine restaurant' (Swartz 2010). For Friend, yoga, like food, is a consumable product, and his brand, Anusara, signifies better product quality.

Twenty-two years after his 1989 visit to India, Friend was invited to lead the grand finale of the 2011 Wanderlust Festival. ${ }^{3}$ Bringing Wanderlust to a close, Friend suggested that that year's festival was particularly 'auspicious' because it fell on the fiftieth anniversary of the death of Nityananda (d. 1961) (Buckner

ashram is a South Asian monastic retreat centre for religious study and training, usually under the guidance of a guru.

3 The Wanderlust Festival is a large-scale music and yoga festival (see Wanderlust Festival 2011). 
2011), a figure identified in Siddha Yoga as a former guru of the tradition. In this way, Friend publically linked his mass-marketed postural yoga brand not just with tantra, but to Siddha Yoga in particular. ${ }^{4}$

All of this raises questions regarding the ways that postural yoga is effectively mass marketed to large audiences of consumers. How, after all, did an Ohio-born former financial analyst who grew up in the Houston suburbs become the founder of the most widely consumed, tantra-inspired postural yoga system in the world?

I ask and attempt to answer that question by contextualizing Friend and Anusara Yoga within the social milieu of contemporary consumer culture. It turns out that the model of brand image management - branding is systematic and pervasive in contemporary consumer culture - is effective for understanding the popularization of yoga today. 5 Throughout yoga's history, proponents have established and acknowledged authority primarily through lineages based on transmission from guru to disciple; however, beginning in the late-twentieth century, yoga proponents also established and acknowledged authority by branding and marketing yoga in urban areas across the world.

In this paper, I evaluate the context in which yoga became subject to a sequential branding process: selection, introduction, elaboration, and fortification. ${ }^{6}$

4 Friend set this precedent as early as 1998 when he officially located himself and Anusara Yoga in the Siddha Yoga lineage with the following epigraph to the Anusara Yoga Teacher Training Manual: 'This manual on teaching hatha yoga is lovingly offered at the lotus feet of my yoga teacher, Gurumayi Chidvilasananda, who taught me the most important element of teaching yoga-divine love' (Friend 2009). Dawn Dobni and George M. Zinkhan suggest that, although the definition of brand image is not stable, there is consensus concerning four essential elements of the concept: 'brand image is the concept of a brand that is held by the consumer'; 'brand image is largely a subjective and perceptual phenomenon that is formed through consumer interpretation, whether reasoned or emotional'; 'brand image is not inherent in the technical, functional or physical concerns of the product. Rather, it is affected and molded by marketing activities, by context variables, and by the characteristics of the perceiver'; and 'where brand image is concerned, the perception of reality is more important than the reality itself'. (Dobni \& Zinkhan 1990: 118.)

6 I am drawing from C. Whan Park, Bernard J. Jaworski, and Deborah J. Maclnnis' normative framework of brand concept management consisting of a sequen-
I argue that my evaluation of Iyengar Yoga, Siddha Yoga, and Anusara Yoga illustrates how the model of brand image management is effective for understanding a broader phenomenon, that is, the contemporary global popularization of postural yoga. I trace the steps through which two first-generation yoga entrepreneurs, Iyengar and Muktananda (1908-82), constructed yoga brands - Iyengar Yoga and Siddha Yoga respectively. I then suggest that Friend is a second-generation yoga entrepreneur who selected from Iyengar Yoga and Siddha Yoga and subsequently introduced, elaborated, and fortified the Anusara Yoga brand. He associated his brand with his own persona, tantric ideas, and biomechanical wares, all of which were attractive to large target audiences consisting of late-twentieth and early twenty-first century consumers. I suggest that Anusara Yoga is particularly illustrative of contemporary yoga branding not only because of its success as a result of brand image management, but also because of ways in which it illustrates gaffes in brand image management.

\section{Branding yoga}

Numerous twentieth-century events and individuals were significant portents of yoga branding. In many areas of the industrialized world, most notably urban centres in India, North America and Western Europe, the increase in access to information about worldviews and practices combined with the decreasing stigma around choosing from a plurality of worldviews and practices resulted in a competitive marketplace. Yoga proponents sought to disseminate yoga to the general populace. In order to do that, yoga needed to stand out in the marketplace amongst available products and services by being packaged in ways that made it seem valuable, accessible, and unique.

In response to early twentieth-century transnational ideas and movements, including military calisthenics (Sjoman 1996), modern medicine (Alter 2004), and Western European and American physical culture (Singleton 2010), proponents constructed new postural yoga systems. ${ }^{7}$ Postural yoga emerged

tial process of selecting, introducing, elaborating, and fortifying a brand concept, which guides the brand image over time (Park, Jaworski \& Maclnnis 1986: 135-45).

7 Prior to the twentieth century, posture practice was not central to any yoga tradition (see Alter 2004, De Michelis 2005, Singleton 2010). Hatha yoga, which developed as an adjunct to the South Asian Nath yoga tradition's practices, did involve a variety of postures 
'as a hybridized product of colonial India's dialogical encounter with the worldwide physical culture movement' (Singleton 2010: 80). The methods of postural yoga were specific to the time and would not have been considered yoga prior to this period of Indian history (Singleton 2010: 177). In fact, postural yoga was the 'cultural successor' of 'established methods of stretching and relaxing' which were already common in parts of Western Europe and the United States (Singleton 2010: 154). Until widely influential yoga gurus, such as Krishnamacharya and Sivananda, began associating such methods with yoga, they were not yet associated with yoga outside of India, but with female physical culture and gymnastics (Singleton 2010: 154).

Training students in the 'pan-Indian hub of physical culture revivalism' in Mysore, India, from the $1930 \mathrm{os}$ to the 1950s, Krishnamacharya constructed an aerobic yoga system whereby the practitioner performed postures in repetition and in sequence (Singleton 2010: 176-7). Sivananda also taught a postural yoga system in Rishikesh, India. Unlike Krishnamacharya, he circumvented the traditional guru-disciple relationship by distributing English-language pamphlets on yoga throughout India and abroad (Strauss 2005: 45). He formalized his yoga dissemination when

but only in preparation for 'internal sexual practices', that is, the tantric manipulation of the subtle body (Samuel 2008: 279, 336). In nineteenth-century India, the tantric manipulation of the subtle body began to be elided from popular yoga practice because of the negative view of tantra and hatha yoga among orientalist scholars and Hindu reformers (Singleton 2010: 41-80). Unsurprisingly, the yoga systems that underwent the greatest degree of popularization were those postural varieties that elided tantric elements completely, such as Iyengar Yoga and Bikram Yoga. Though hatha yoga is the traditional source of postural yoga, equating them does not account for the historical sources, which include British military calisthenics (Sjoman 1996), modern medicine (Alter 2004), and the physical culture of European gymnasts, body-builders, martial experts, and contortionists (Singleton 2010). All of these influenced figures responsible for constructing postural yoga, including Tirumalai Krishnamacharya (1888-1989) and Sivananda Saraswati (1887-1963) (Strauss 2005, Singleton 2010). Such an equation would also fail to account for the variety of methods and aims that hatha yoga systems themselves have embraced since their emergence in the tenth to eleventh centuries and which are not present in postural yoga, including supernatural and other temporal powers (see White 1996, White 2009). he established the Divine Life Society in 1936, and its culmination occurred in 1959 with his Englishlanguage book, Yogic Home Exercises: Easy Course of Physical Culture for Modern Men and Women.

Some of Krishnamacharya and Sivananda's students encouraged an association between physical fitness methods and aims with yoga in the popular imagination by constructing and mass marketing postural yoga brands. With these developments, the aims of postural yoga came to include popular modern conceptions of physical fitness, stress reduction, beauty, and overall wellbeing (De Michelis 2005, Newcombe 2007, Singleton 2010).

Krishnamacharya had arguably the most impact on postural yoga's entry into the global marketplace, since it was his students, most notably Iyengar, K. Pattabhi Jois (1915-2009), and T. K. V. Desikachar (b. 1938), who most successfully constructed yoga brands and marketed those brands to the general populace in urban centres across the world during the second half of the twentieth century.

Some of Sivananda's students were also influential in this regard. One German student, Boris Sacharow, having never actually travelled to Rishikesh, became a disciple through Sivananda's English-language pamphlets and eventually opened the first yoga school in Germany (Strauss 2005: 41-2). Another student, Vishnudevananda (1927-93) established International Sivananda Yoga Vedanta centres and ashrams in locations around the world as well as the Sivananda Yoga Teachers' Training Course, which serves to regulate Sivananda Yoga.

Other mid-twentieth century yoga proponents constructed new soteriological yoga systems and marketed them to the general populace. The 1960 s provided ideal timing for the popularization of such systems, since that decade witnessed the BritishAmerican counterculture, which called for a religiosity radically distinct from what were perceived as the oppressive, puritanical orthodoxies of the previous generation. And, although twentieth-century immigration from India to the United States and Western Europe had been rare due to legal restrictions, those restrictions were largely lifted in the 1960 s, leading to an influx of immigration from India, especially to the United States, the United Kingdom, and France. Many participants in the British-American counterculture eagerly looked to yoga gurus and their wares for soteriological insights and techniques. In turn, several Indian gurus - among them were Muktananda of Siddha Yoga, Maharishi Mahesh Yogi (b. 1918-2008) of Transcendental Meditation, and Bhaktivedanta 
Prabhupada (1896-1977) of the International Society for Krishna Consciousness - exploited these robust trends by marketing soteriological yoga systems to popular audiences.

Socio-economic shifts were also significant. The twentieth century featured a shift toward mass production and mass consumption in urban areas across the world, and new groups of consumers increasingly exercised choice with regard to the products and services they purchased (Bocock 1993: 22). In the second half of the twentieth century, economies increasingly shifted from being industrial and based on mass production to a more personalized model, based on 'customized products for individualistic consumers' (Russell 1993: 56). Consumer culture became based on individualized products and services. Mike Featherstone describes this consumer culture:

In contrast to the designation of the 1950 as an era of grey conformism, a time of mass consumption, changes in production techniques, market segmentation and consumer demand for a wider range of products, are often regarded as making possible greater choice (the management of which itself becomes an art form)...

(Featherstone 2007: 81).

Today, consumption depends on whether or not products and services are linked to consumer desires - according to Jean Baudrillard, consumers construct a desired self-identity by consuming what they think signifies that self-identity (Baudrillard 2002) - through the use of signs and symbols (Bocock 1993: 3). Market researchers and advertising campaign managers do this by establishing brand images for everything from soap dishes to sporting goods (Bocock 1993: 22).

It was this historical period which witnessed an explosion of sundry yoga brands into the marketplace. Entrepreneurs brand yoga in the same ways that other products and services are branded, by 'giving it a name, term, design, symbol, or any other feature that identifies one seller's goods or services as distinct from those of other sellers' (American Marketing Association 2012). Branding requires marketers to uniquely package their products by mythologizing them, a process that serves to 'position' them in consumers' minds (Einstein 2008: 12). Branding mythologizes yoga products and services, ranging from mats and pants to styles and teachers, and thus they come to signify various meanings to consumers. And one of the most common themes is that yoga signifies self-development. It is a tool that will enable consumers to become better people through physical and psychological transformations (De Michelis 2005, Newcombe 2007, Singleton 2010).

More than those of any other form of modern yoga, postural yoga brands are widely consumed in popular culture. Dominant ways of conceptualizing the body in contemporary consumer culture are important for understanding why postural yoga underwent popularization (see, e.g., Jain 2012a). In consumer culture, the inner and outer bodies are 'conjoined', meaning that body enhancement reflects self-development (Featherstone 1991: 171). Consequently, the market for physical culture regimes, in which body enhancement requires rigorous selfcontrol through diet and exercise (Albanese 2007, Singleton 2010), has witnessed robust growth. Furthermore, biomedical discourse dominates the way people think and talk about their bodies (Turner 1997: 35). Successful postural yoga entrepreneurs exploit such trends in the global fitness and health market by managing their brand images in ways that make them represent these dominant ways of conceptualizing the body and self-development.

Many yoga proponents prescribe yoga, not as an all-encompassing worldview or system of practice, but as one aspect of self-development, which can be consumed in combination with other worldviews and practices. All of this serves to make yoga attractive to large target audiences of consumers who do not want to go to an Indian ashram nor seek out a proselytizing guru in order to 'do yoga' as it is colloquially put. Instead of relying on yoga transmission through the traditional guru-disciple relationship in the isolated context of an ashram, yoga entrepreneurs build large organizations for mass marketing the products and services associated with their yoga brands.

Today, most consumers shop for conveniently located yoga classes which are open to the general populace. More generally, consumers have 'substantial and unpredictable decision-making power in the selection and use of cultural commodities' (Willis 1990: 137). Entrepreneurs, in turn, construct brands that they think consumers will buy. Consumers, however, are not the only agents. Rather the construction of brands is based on a dialectical exchange between the entrepreneurs who produce desires and needs for goods and services and consumers who choose them based on individual preferences (Holt 2002: 71-2). In this way, cultural production is integrated into commodity production and consumption. The result is not a homogenous set of shared meanings and values 
but rather a heterogeneous culture with various overlapping groups (Arnould \& Thompson 2005: 868-9).

The concomitant commodifying processes result in ever-new yoga systems depending on marketing strategies and popular demands. Change is not new to the history of yoga (see, e.g., Samuel 2008, Singleton 2010, White 2012). But what differs today is the extent to which the media saturates consumer cultures, which brings consumers into near-constant contact with advertising and causes yoga products and services to change at a rate never seen before in its history.

Though packaged differently, popularized systems of yoga offer similar ends: self-development through physical and psychological transformation (De Michelis 2005, Newcombe 2007, Singleton 2010). Thus the only way for the consumer to differentiate one set of yoga products and services from another is to interpret the meaning the brand signifies. This is an important process for the consumer, since consumption is entwined with constructing a sense of identity (Giddens 1991, Bocock 1993, Baudrillard 2002). Consequently, yoga entrepreneurs must manage their brand images in ways that make consumers feel personally connected to them.

In the economic circumstances of market capitalism, however, a personal connection with a product is not usually enough to make it yours. Rather the consumption of yoga products and services almost always requires the consumer to spend money. The amount of spending depends largely on brand. A consumer can purchase a pair of yoga pants with an unfamiliar brand at the popular retail store, Target, for $\$ 19.99$, or purchase a pair from Lululemon, a highend yoga-apparel brand that on average costs $\$ 98$ for yoga pants. On the retail website Amazon, the consumer can choose from a variety of yoga mats with unfamiliar brands for under $\$ 20$, or she can go to a specialty shop and purchase a stylish Manduka brand yoga mat, which will cost as much as $\$ 100$. And all that does not include the cost of yoga classes, which widely range from $\$ 5$ to over $\$ 20$ per class. And if a consumer is really dedicated to investing money in yoga, for thousands of dollars she can purchase a spot in a yoga retreat in locations throughout the United States, Europe, or even in the Bahamas or Brazil, with yoga teachers marketing their own popular brands, such as Bikram Choudhury, whose brand is Bikram Yoga, or John Friend, whose brand is Anusara Yoga. Spending on yoga is steadily increasing. In the United States alone, spending doubled from $\$ 2.95$ billion to $\$ 5.7$ billion from 2004 to 2008 (Macy 2008).
The meaning of yoga is conveyed, however, not only through what products and services yogis choose to purchase but also what they choose not to purchase. ${ }^{8}$ In other words, consumption can require an exchange of money and commodities, and the amount of money spent on commodities largely depends on the brand choices of individual consumers, however, consumption can also lack an exchange of money and commodities. Many contemporary yogis, in fact, oppose the commodification of yoga by consuming free yoga services and rejecting certain yoga products.

For example, the yoga practitioner can now opt out of purchasing a yoga mat altogether, or attend donation-based yoga classes. ${ }^{9}$ This phenomenon is becoming especially prevalent in New York City where organizations - most popular of which is Yoga to the People - which provide donation-based yoga classes or yoga classes that do not require a mat, are growing.

Yoga to the People opened its first studio in 2006 with a donation-only structure. The website is adorned with the following 'mantra':

There will be no correct clothes

There will be no proper payment

There will be no right answers

No glorified teachers

No ego no script no pedestals

No you're not good enough or rich enough

This yoga is for everyone

This sweating and breathing and becoming

This knowing glowing feeling

Is for the big small weak and strong

Able and crazy

Brothers sisters grandmothers

The mighty and meek

Bones that creak

Those who seek

This power is for everyone

(Yoga to the People 2011b).

8 A perusal of recent articles in popular yoga publications, such as Yoga Journal, evidences that many contemporary practitioners of postural yoga colloquially self-identify as yogis. In South Asian yoga traditions, the term was not in use until the twelfth- to thirteenth-century emergence of the Nath Yogi tradition. According to David Gordon White, 'The Nath Yogis were and remain the sole South Asian order to selfidentify as yogis' (White 2012: 17).

9 The first purpose-made yoga mat was manufactured and sold by Hugger Mugger in the 1990s (Brooks 2003). 
In certain ways, Yoga to the People is akin to commodified yoga brands. Consider the benefits Yoga to the People promises: yoga helps people 'look and feel great'; 'yoga helps tone and sculpt muscles while gaining strength, flexibility and balance'; and '[in] a world of stress, yoga helps people decompress and achieve a sense of inner peace, aiding in healing injury or disease' (Yoga to the People 2011a). These are all benefits popularly associated with yoga. Yoga to the People also sells yoga apparel, though the website states, 'Our clothing was not produced with an emphasis on "maximizing" profits. [The] emphasis is to spread the word. . . to share the intention of YTTP which is to put the essence or spirit of yoga before the business of yoga.' (Yoga to the People 2011c.)

For the creator of Yoga to the People, Greg Gumucio, and those who consume the services associated with his brand, yoga's meaning transcends its commodities. Gumucio states, 'I truly believe if more people were doing yoga, the world would be a better place' (Billard 2010a). The anti-commodification brand of Yoga to the People signifies that meaning. The individual who chooses Yoga to the People still acts as a consumer even if consumption does not require the exchange of money. And the consumer chooses Gumucio's brand as opposed to others because of that brand's success in capturing what yoga means to the consumer.

Some postural yogis reject the yoga mat for its perceived over-commodification (Billard 2010b). The mat, for most postural yogis, is a necessity. It does not just meet the utilitarian need to perform necessary postures without slipping or to mark one's territory in a crowded yoga class, but also signifies various meanings. The mat signifies a 'liminal space' set apart from day-to-day life as one participates in a self-developmental ritual of rigorous physical practice. ${ }^{10}$ It is also

10 Citing Arnold van Gennep on rites of passage, De Michelis argues that a postural yoga class functions as a 'healing ritual of secular religion' (De Michelis 2005: 252; on rites of passage, see van Gennep 1965). Also citing Victor Turner, De Michelis argues that the postural yoga class functions as a 'liminal space': 'Spatially, practitioners remove themselves from the hustle and bustle of everyday life to attend the yoga class in a designated 'neutral' (and ideally somewhat secluded) place' (De Michelis 2005: 252; on ritual liminality, see Turner 2008). The practitioner undergoes both physical and psychological transformations and healing before being reintroduced to 'everyday life' (De Michelis 2005: 252-7). I argue that, for those postural yogis who use yoga mats, the liminal space of the yoga class is, in part, demarcated by the mat. oftentimes a status symbol. But yogis who reject the mat argue that they are not necessary, that they interfere with practice, and that they are simply commodities without any profound meaning. One such yogi argues, 'The ecstasy of yoga can't be contained by a mat' (Billard 2010b). Such yogis choose brands of yoga that do not require the mat, such as Laughing Lotus (Laughing Lotus 2012), which has studios in New York and San Francisco, because those brands are believed to better signify the meaning of yoga.

These yoga practitioners are not the only ones who condemn the commodification of yoga. Some scholars do too, arguing that the commodification of yoga is not compatible with its authentic form. Popularized forms of postural yoga are sometimes treated as a mere accretion that distracts from the purity of the true or original yoga tradition. Georg Feuerstein, for example, considers 'the popularization of yoga as potentially destructive of the yogic heritage', since it embodies 'distortions' of yoga. He adds that postural yoga is inauthentic because 'fitness and health', some of the aims of postural yoga, 'are simply not final objectives of traditional yoga', and suggests that contemporary practitioners should focus on "The "lost" teachings of yoga-that is, the authentic teachings as found in the traditional literature and as imbued with life by living masters' (Feuerstein 2003). More broadly, Jeremy Carrette and Richard King argue against the commodification of what were traditional religious wares: 'What is being sold to us as radical, trendy and transformative spirituality in fact produces little in the way of a significant change in one's lifestyle or fundamental behaviour patterns (Carrette \& King 2005: 5).

Yet, although the commodities of consumer culture are manifestations of it, it would be a mistake to reduce consumer culture to those commodities (Featherstone 1991; Bocock 1993; Tomlinson 1999: 83). And a close evaluation of yoga brands in particular suggests that, although the commodities of popularized forms of yoga are manifestations of it, it would be a mistake to reduce yoga to its commodities. The yoga market, in accordance with consumer culture in general (Featherstone 1991: 112; Bocock 1993), destabilizes the basic utility of yoga commodities and services and assigns to them new meanings. Yoga and commodification are not mutually exclusive; rather they stand in a symbiotic relationship to one another. In short, yoga brands, whether they signify a particular teacher, style, or product, signify more than just the fulfillment of utilitarian needs, rather the fulfillment of what are perceived as self- 
developmental needs become contained in the brand.

In order to illustrate how yoga brands signify various meanings, I suggest that the reader consider the following example of how this occurs in another area of consumption, that of breakfast. Within a single household a variety of breakfast cereals fill the cabinet as a reflection of the various desires and needs of individual members. In the refrigerator, one may find a variety of options with regard to milk and fruit to layer atop the cereal. Each constructs a unique breakfast option by picking each part to construct a whole suited to individual preferences. One constructs one's breakfast based on what choices signify. A consumer who values health may choose the Kashi organic cereal and skimmed milk. A consumer who values strength and heroism may choose the Kellogg's cereal box featuring Spiderman. And the consumer who values convenience and social status may skip breakfast cereal altogether and instead stop at Starbucks for one of their familiar cups of coffee to carry with them into work. Consumers construct individual breakfasts suited to their preferences, and their choices, like all choices in consumer culture, mean more than just the stuff - grains, marshmallows, or caffeine - of the breakfast itself.

In the same way, choices in the area of yoga mean more than just the stuff - teachers, spandex, retreats, mats, or studios - of the products and services themselves. In the yoga market, the process of yoga branding and the process of the economic exchange of yoga commodities are distinct, even though they almost always overlap. Yoga brands are saturated with meaning insofar as they signify what consumers deem valuable, and consumers choose brands based on what they consider the most unique and accessible path to get there.

\section{First-generation yoga brands: lyengar Yoga and Siddha Yoga}

Two yoga brands, Iyengar Yoga and Siddha Yoga, are illustrative of how first-generation yoga entrepreneurs popularized postural and soteriological yoga systems by introducing them into the late twentiethcentury global marketplace.

After studying yoga with Krishnamacharya, Iyengar became a postural yoga instructor in Pune, where he attracted several wealthy and influential celebrities as his clients. With their patronage, in the 1950s, he travelled to London, Switzerland, the United States and Paris to teach postural yoga and, by his third trip to London in 1960, he had established a permanent group of students. From this point on, he would return every year to teach them.

In response to the robust trends in the global fitness market, Iyengar selected from Krishnamacharya's teachings and elaborated upon those teachings in order to create Iyengar Yoga as a physical fitness brand. Iyengar prescribed a rigorous and disciplined form of body maintenance, which uses fitness tools, such as belts, bricks, and ropes. It was convincingly linked to biomedical understandings of the body and could be chosen as an aspect of selfdevelopment that was easily incorporated into personalized regimens (De Michelis 2005: 197-8).

As a consequence of many steps toward elaborating and fortifying his yoga brand, Iyengar succeeded in mass marketing it in the 1960 s and 1970 s. In arguably the most significant event in the process of elaborating Iyengar Yoga, Iyengar published his Light on Yoga (1966), which immediately underwent mass marketing. The book quickly became the global standard reference on postural yoga (De Michelis 2005: 198). It made postural yoga particularly accessible because it included step-by-step instructions so that individuals could choose yoga as one part of their self-development regimens and incorporate it into their routines according to their personal needs and desires - students could choose from a variety of postures and other techniques - without having to give up other lifestyle commitments.

In the late 1960s and 1970s, a combination of events allowed for a further consolidation of the Iyengar Yoga brand. Yoga classes became available at American YMCAs as Iyengar's students began to teach it. For example, having hosted several yoga gurus, including Iyengar, for public seminars in Chicago, Marilyn Englund began teaching her own yoga classes at Chicago area YMCAs in 1966 (Leviton 1990: 65). By 1971, she had 550 students per week in twenty-seven classes (Leviton 1990: 65). Iyengar's London students began teaching in the physical education department of the Inner London Education Authority (ILEA) (Newcombe 2007: 42). Yoga classes became available at the Clapton Adult Education Institute in London in 1967 . Classes taught by Iyengar's students at American YMCAs and London institutions were thoroughly postural yoga classes that were deemed beneficial for a variety of consumers, regardless of various other commitments. ${ }^{11}$

11 Consider, for example, the following argument by ILEA officials: 'Instructional classes in Hatha Yoga need not and should not involve treatment of the 
Most significantly, in 1975, Iyengar established the Ramamani Iyengar Memorial Yoga Institute in Pune. The Institute, which functioned as the centre for teacher training, greatly augmented the number of yoga teachers receiving official training in Iyengar Yoga. It functioned as the headquarters from which to disseminate Iyengar Yoga (De Michelis 2005: 200). In this way, the Iyengar Yoga brand could be constructed, marketed, and perpetuated across product lines. In short, it could be managed more effectively.

By 1990, a family of senior Iyengar Yoga teachers, the Mehtas, could report: '[Iyengar] has several million students all over the world following his method. There are Iyengar Institutes and centers in the US, the UK, Europe, Australia, Canada, Israel, Japan, New Zealand, and South Africa, as well as India' (Mehta, Mehta \& Mehta 1990: 9). Since then, Iyengar has established the following Iyengar Yoga Institutions: the Light on Yoga Research Trust, which serves to propagate Iyengar Yoga primarily through funding research into the practice; the Iyengar Yogashraya, a major Iyengar Yoga centre in Mumbai, India; and the Youth's Offerings to Guruji, which serves to propagate Iyengar Yoga primarily through publishing books and producing other Iyengar Yoga products, such as belts and bricks (Ramamani Iyengar Memorial Yoga Institute 2009a). Basically, Iyengar Yoga has undergone continuous, exponential growth. Today, there are thousands of Iyengar Yoga teachers and millions of practitioners in over seventy countries across the world (Ramamani Iyengar Yoga Institute 2009b).

Muktananda constructed a very different yoga brand than Iyengar Yoga. In 1960s India, Muktananda selected from the teachings of his guru, Nityananda (d. 1961), and philosophical and practical traditions that pre-dated him, especially yoga, Vedanta, and Kashmir Shaivism, in his construction of a unique persona and set of tantric spiritual wares, which he enveloped under the brand name, Siddha Yoga (e.g., Caldwell 2001, Williamson 2005, Jain forthcoming). Siddha Yoga signified God-realization through the kripa or 'grace' of the guru.

Muktananda was known for his democratic, experiential approach to spirituality - God was within 'everyone'. In Siddha Yoga, God-realization comes in the form of shaktipat diksha, an initiation through the spontaneous awakening of the previously dormant

philosophy of Yoga. They can be justified only as a form of "Keep fit" or physical training' (ILEA Further and Higher Education Sub-Committee Papers 1968, quoted in Newcombe 2007: 41). feminine divine energy, shakti, believed to reside in everyone. The Siddha Yoga guru transmits shaktipat to the disciple in an initiatory ritual involving a look, a touch, or Muktananda's initiatory method-ofchoice, a blow to the head with a wand of peacock feathers. ${ }^{12}$

Though Muktananda's understanding of shaktipat was akin to those found in traditional contexts, his method of disseminating it was not. Muktananda first introduced Siddha Yoga to disciples at his ashram, Shree Gurudev Ashram (later renamed, Gurudev Siddha Peeth), which resembled a European or American style retreat centre and hosted large numbers of disciples from around the world. Disciples visiting or living at the ashram could choose the extent of their commitment, ranging from becoming a permanent monastic member of Muktananda's community where Siddha Yoga functioned as an allencompassing worldview and system of practice to incorporating Siddha Yoga into one's spiritual repertoire as one part of an eclectic path towards a realization of God or self.

Based on Muktananda's success in attracting disciples, one could judge him to be an astute entrepreneur. Aware that the global market for spiritual wares required marketers to calculate the costs to the brand for wares associated with unpopular ideas or practices, Muktananda elaborated Siddha Yoga by publically embracing the popular dimensions of tantra, such as bhakti or 'devotion' and meditation, rather than the esoteric dimensions, such as the ritual use of intoxicants or sex, that required the practitioner to intentionally transgress normative ethical and purity standards in order to become aware of the reality of non-duality. ${ }^{13}$

12 Paul E. Muller-Ortega describes the function of that initiation: 'When the essential, enlightened consciousness of the sadguru [true guru] enters the disciple, shaktipat occurs. And it is thought to destroy the root or foundational impurity of spiritual ignorance. In this way, shaktipat ignites the fire that will culminate in the achievement of liberation and enlightenment' (Muller-Ortega 1997: 409). For Muktananda, 'the grace of the Guru' is shaktipat (Muktananda 1994: 12).

13 Sarah Caldwell suggests that Muktananda's selective strategy is analogous to what David Gordon White calls the 'dissembling strategy' of Abhinavagupta, the medieval Kashmiri Shaiva responsible for reconstructing the Kula tradition. Abhinavagupta relegated the transgressive dimensions of the Kula tradition to secrecy in order to win over the hearts and minds of 
Muktananda claimed that Siddha Yoga was distinct from traditional or 'orthodox' systems in its democratic approach (Muktananda 1985: 189). Muktananda elaborated the Siddha Yoga brand by embracing the dominant normative ethical standards of late twentieth-century urban centres where democratic religious ideals prevailed. Although Siddha Yoga disciples relied on the grace of the guru, they all were equally dependent in this way. Furthermore, they all had equal access to teachings and practices, were required to perform ethical actions, and were viewed as having God within them.

In the 1970s, Muktananda fortified the Siddha Yoga brand by means of his 'world tours', which involved three trips to numerous parts of the world but with especially long periods in the United States in 1970, from 1974 to 1976 , and from 1978 to 1981 . The very method by which people learned Siddha Yoga changed as, instead of relying exclusively on oneon-one transmission at the Gurudev Siddha Peeth ashram, Muktananda went out to urban centres in search of disciples, actively marketing the Siddha Yoga brand.

Muktananda further fortified the brand in 1974 when he introduced 'the Intensive', a choreographed retreat where initiates received shaktipat. This made the bestowal of shaktipat upon hundreds - and today, thousands - of people at a time efficient, cost-effective, and available for immediate consumption. ${ }^{14}$ By commodifying shaktipat in this way, especially with regard to admission charges for an Intensive, Muktananda 'locked-in' consumers, meaning he decreased the likelihood that they would pursue other

the general Kashmiri populace' (see White 1999: 255; Caldwell 2001: 25).

14 Initiates, however, have to pay for admission to an Intensive where they receive shaktipat, thus making shaktipat inaccessible to those who cannot afford the price of admission. Nevertheless, as articulated by Muller-Ortega, making shaktipat readily accessible to a global audience made Siddha Yoga unique: 'Because of shaktipat's historical rarity and relative unavailability, the notion that Swami Muktananda should have made shaktipat attainable on a wide scale around the world is quite noteworthy. After many centuries of barely being available even in India, its sudden and relatively easy accessibility marks an unprecedented and significant historical shift. It is only when we fathom the rarity of what Swami Muktananda professed to be offering to the world that we can begin to appreciate the boldness and genius of his decision to bring shaktipat out of its millennial obscurity. (Muller-Ortega 1997: 410.) religious goods in the marketplace, since they had made an investment of energy, time, and money in Siddha Yoga. ${ }^{15}$

Consumers' commitment to Siddha Yoga, however, cannot be reduced to consumer lock-in. The testimonies of Siddha Yoga practitioners suggest that, more than anything else, long-term commitment to Siddha Yoga was a result of what it provided in terms of a remystification of the world. Spiritual seekers associated the Siddha Yoga brand with Muktananda, who was perceived as a siddha or 'perfected master', and with shaktipat, which involved an experience of nothing less than God.

Muktananda took additional steps towards fortifying the Siddha Yoga brand by supporting Siddha Yoga centres, which provided a sense of group identity to individuals who did not have regular direct contact with the guru himself. In 1975, he established the SYDA (Siddha Yoga Dham Associates) Foundation, the organization responsible for the financial and organizational infrastructure of Siddha Yoga outside of India. Organizational developments included the introduction of Siddha Yoga courses and teacher training programmes as well as establishing departments for the publication of Siddha Yoga books. All of this enabled the construction, marketing, and perpetuation of the Siddha Yoga brand across product lines.

Successful brand image management resulted in thousands of people from urban areas across the world choosing Siddha Yoga. By the time of Muktananda's death in 1982, Siddha Yoga ashrams and centres were present in India, the United States, Europe, and Australia. In the last year of Muktananda's life, however, there were major gaffes in the guru's brand image management when he transgressed the normative ethical standards that Siddha Yoga embraced by engaging in sexual rituals involving young women and girls (see Caldwell 2001, Jain forthcoming). With accusations of improprieties, brand success declined. Yet Muktananda's successor, Chidvilasananda, and her disciples have managed to keep the brand competing in the global market for spiritual wares. Today, there are Siddha Yoga ashrams or centres in thirty countries worldwide (SYDA Foundation 2012), and Friend is only one amongst thousands of contemporary yoga consumers to choose Siddha Yoga.

15 The greater the setup costs, the less likely consumers are to move to another, even better, ware, especially when such a move requires additional costs (Zauberman 2003: 405-19). 


\section{A second-generation yoga brand: Anusara Yoga}

On the one hand, Iyengar and Muktananda, firstgeneration yoga entrepreneurs, selected from the non-branded yoga systems of Krishnamacharya and Nityananda respectively in order to construct new yoga brands that would be mass marketed to the general populace. On the other hand, Friend, a secondgeneration yoga entrepreneur, selected from previously existent yoga brands, Iyengar Yoga and Siddha Yoga, in order to construct the Anusara Yoga brand. Having selected and introduced his yoga brand in the 1990s, he elaborated and fortified it throughout the early 200os. Successful brand image management resulted in hundreds of thousands of people from urban areas across the world choosing Anusara Yoga in what was now a diversified global yoga market.

Before introducing his yoga brand, Friend had had a laudable yoga career. He studied with the most famous living postural yoga teacher, Iyengar, and spent four years on the Board of Directors of the Iyengar Yoga National Association. In 1995, he returned to the Ramamani Iyengar Memorial Yoga Institute for another one-month intensive yoga programme. He also studied with other world famous teachers, including Desikachar, Patabhi Jois, and Indra Devi (1899-2002). None of them affected him as powerfully as Chidvilasananda, the guru of Siddha Yoga (Williamson forthcoming). Friend maintained ties to Siddha Yoga - he spent almost every summer from 1992 to 2004 living and teaching in the Hatha Yoga Department at the Siddha Yoga Shree Muktananda Ashram in South Fallsburg, New York (Friend 2009b). ${ }^{16}$

All of Friend's hours of study under various yoga proponents significantly influenced his selection process as he constructed his own idiosyncratic yoga sys-

16 Further solidifying his ties to Siddha Yoga, Friend accepted an invitation from Chidvilasananda to join the Siddha Yoga Professors and Scholars Department. Through his involvement in that department, Friend befriended many scholars of Siddha Yoga, including Douglas Brooks, Paul Muller-Ortega, William Mahony, and Sally Kempton (then Swami Durgananda), thus forming a network that would continue to influence his thinking about and dissemination of yoga (Williamson forthcoming). These scholars would eventually collaborate on the edited volume, Meditation Revolution, which offers a history and theology of Siddha Yoga (Brooks et al. 1997). In August 2004, Friend taught his last yoga programme at the Siddha Yoga ashram after which Gurumayi closed the ashram to visitors (Williamson forthcoming). tem. More than anything else, Friend embraced the rigorous physical fitness dimensions of Iyengar Yoga and the non-dualistic tantric philosophy of Siddha Yoga. After realizing the conflict between Siddha Yoga philosophy and Iyengar Yoga, which maintained the dualistic philosophy of the Yoga Sutra and emphasized physical fitness with what Friend perceived to be the loss of spirituality (Williamson forthcoming), Friend set out to construct his own form of tantra-inspired postural yoga, which would resolve the perceived incompatibilities between Siddha Yoga and Iyengar Yoga.

When Friend introduced Anusara Yoga in 1997, the brand represented a mix of postural yoga, a tantric, non-dualist philosophy, and a life-affirming and light-hearted approach that is premised on the idea 'that everything in this world is an embodiment of Supreme Consciousness, which at its essence pulsates with goodness and the highest bliss' (Anusara, Inc. 2009a). Based on his years of studying Iyengar Yoga, Friend adopted certain biomechanical principles but, based on his years studying Siddha Yoga, he gave them a non-dualist tantric spin, arguing that their aim was 'to bring the body into alignment with the Optimal Blueprint' (Friend 2009a: 39). In addition to the Anusara philosophy, the selection of books available through Anusara Yoga's website, which features a variety of books on tantric philosophy as well as books on biomechanics (Anusara, Inc. 2009b), evidences Friend's selection from both Iyengar's postural yoga and Siddha Yoga's soteriological yoga.

All of Friend's selective and elaborative strategies resulted in one of the most successful yoga brands in the world. Friend convinced hundreds of thousands of consumers to choose his yoga brand over others, and the demand for his products quickly went global. What made Friend's yoga brand stand out most was that it signified the idea that goodness is present in everyone in a life-affirming way. According to Friend, 'Tantra is not only the most elegant and sophisticated system, but it's the one that aligns with my heart because it sees that the very essence of life is joy or love and that there's a goodness to life' (Williamson forthcoming). According to Lola Williamson, who conducted several interviews with Friend and his students, 'positively affirming his students with lightness and humour quickly became the hallmark of Friend's teaching style' (Williamson forthcoming).

In 1998, Friend took an important step toward fortifying his brand when he developed instructions for how to teach Anusara Yoga and published them as the Anusara Teacher Training Manual (2009). 
With over a thousand licensed teachers worldwide, Anusara became one of the most common yoga systems in the global yoga market.

In addition to consumers who attended yoga studios where teachers taught Anusara Yoga, hundreds and sometimes thousands of people gathered together at yoga workshops, conferences, and festivals to hear Friend disseminate his teachings on yoga as fitness and spirituality. Friend offered workshops all over the United States and the world at destinations as far as Taipei, Tokyo, Copenhagen, and Munich.

Friend's steps toward fortifying the Anusara Yoga brand effectively locked-in consumers. Committed students spent thousands of dollars on yoga classes, teacher-training workshops, and travelling costs, not to mention other Anusara Yoga products, ranging from products in the Anusara yoga clothing line to Anusara Yoga mats and water bottles (Anusara, Inc. 2009 d). Friend even collaborated with the corporate fitness clothing apparel giant, Adidas, and the corporate yoga accessories giant, Manduka.

Consumers' commitment to Anusara Yoga, however, cannot be reduced to the phenomenon of consumer lock-in. Anusara Yoga, in short, consists of more than just its commodities. Based on numerous interviews with Anusara Yoga practitioners, Williamson (forthcoming) suggests that Anusara Yoga provided a strong sense of community and meaning for individuals who rejected traditional institutionalized religions. Friend offered a form of religiosity that was accessible to a wide audience, since its life-affirming, light-hearted approach, like other successful consumer goods, was not all-encompassing and instead could be integrated as one part of a larger worldview or lifestyle. ${ }^{17}$ Furthermore, Friend appealed to those consumers who desired a form of yoga that involved positive affirmation while simultaneously avoiding doing so with the loss of an emphasis on physical fitness, which was in popular demand amongst yoga consumers.

Anusara Yoga was also successful because, in a way similar to Muktananda, Friend elaborated the

17 'The term "lifestyle", according to Featherstone, is currently in vogue ... within the contemporary consumer culture it connotes individuality, self-expression, and a stylistic self-consciousness. One's body, clothes, speech, leisure pastimes, eating and drinking preferences, home, car, choice of holidays, etc. are to be regarded as indicators of the individuality of taste and sense of style of the owner/consumer.' (Featherstone 2007: 81.)
Anusara Yoga brand by publically embracing the exoteric dimensions of tantra, such as postures, breathing exercises, and devotion, rather than the esoteric dimensions that required the practitioner to deliberately transgress normative ethical standards. In accordance with the Siddha Yoga gurus, Friend never publicly prescribed transgressive techniques. Rather, he prescribed the strict ethical guidelines as articulated for all Anusara Yoga consumers on the Anusara website (Anusara, Inc. 2009c).

Because it successfully signified the meaning of yoga for many consumers, Anusara Yoga was producing millions of dollars a year in revenue. In 2012, Friend was in the middle of one of his world tours, which were an important means of consolidating his yoga brand. This tour was entitled Igniting the Center and began in Encinitas, California, a yoga epicentre, in honour of the new headquarters for Anusara Yoga, called simply, 'The Center', which Friend was building there. But just as Friend enjoyed a place in the limelight in the yoga world for his success as the founder of a growing yoga organization and for what was perceived as his virtuous character, he and his yoga brand became mired in scandals (see Jain $2012 \mathrm{~b}$ ). He was accused of transgressing the ethical guidelines that Anusara Yoga prescribed when he made what were perceived as unethical sexual and financial decisions.

The accusations can be summarized as follows: Friend led a Wiccan coven and had sex with female members; Friend had numerous sexual relationships with married Anusara employees and teachers; Friend violated federal regulations regarding employee benefits by suddenly freezing Anusara, Inc.'s pension fund; and finally, Friend put his employees at legal risk by arranging for them to accept packages of marijuana meant for his personal use (Yoga Dork 2012b). ${ }^{18}$

Suspicion that the accusations were true grew as people learned that four of Anusara Yoga's most senior teachers - Christina Sell, Darren Rhodes, Elena Brower, and Amy Ippoliti - had recently resigned one by one, citing 'professional differences' (Yoga Dork 2012b). Soon after the accusations went public, more of Anusara's most loyal consumers abandoned Anusara Yoga. Two additional senior teachers, Noah Maze and Bernadette Birney, resigned, and Maze stepped down from his position on an interim committee that Friend established to ensure

18 The accusations were re-posted by blogger Yoga Dork in early February from an anonymous site. 
Anusara's survival from the onslaught of the scandals (Yoga Dork 2012b). On her website, Birney added to the scandals, claiming that Friend had 'decided to "heal" his students with "sex therapy"' (Birney 2012).

With the threat of Friend's gaffes permanently damaging the Anusara Yoga brand image, Friend confirmed that he had had sexual relationships with married employees and teachers and that Anusara, Inc. had violated federal regulations regarding employee pension funds (Lewis 2012). Friend also wrote the following to Anusara Yoga teachers:

The central issue now is that the wonderful image and reputation of Anusara yoga has been severely stained in the minds of some, since my personal behavior has been perceived to be out of integrity with Anusara ethics ... the disharmony between my personal image and the values of our school needs to be reconciled, if Anusara is to properly heal ... we are exploring scenarios in which the company is restructured to give teachers more voice and representation not only in areas of brand, ethics and curriculum, but also in the governance and direction of the company itself. (Yoga Dork 2012a.)

He added, 'We must all remember that any missteps by me do not invalidate any of the greatness of the Anusara yoga method' (Yoga Dork 2012a).

Friend and his colleagues are desperately attempting to save Anusara Yoga's brand image. In order to re-invigorate a declining brand image, Friend announced the appointment of Michal Lichtman as $\mathrm{CEO}$ of the new 'teacher-run, nonprofit organization - the Anusara Yoga School', adding that Friend himself would remain only 'founder, student, and teacher of Anusara yoga' (Yoga Dork 2012c).

Some journalistic accounts of the scandals assumed that such changes would make a difference to Anusara Yoga's success in the global market. Stewart J. Lawrence suggests in The Huffington Post that the Anusara Yoga situation reflects the reality for the entire yoga industry, whose future is grim due to the dominance of 'charismatic, guru-based governing structures' rather than 'more modern and democratic' ones (Lawrence 2012).

Friend was not, however, the Anusara Yoga guru. Even though Friend used the term kula (Sanskrit for 'family') to refer to the Anusara Yoga community - a term traditionally applied to disciples gathered around a guru - Friend rejects the label, preferring instead to call himself the founder and (until the re- cent restructuring) general manager of Anusara. But that doesn't mean the infallible attributes often associated with the term guru have not been attributed to him. Until the scandals of 2012, Friend had been considered the paragon of virtue within the Anusara community.

But even if Friend functioned as a guru for the Anusara community, his relationship to the Anusara brand is no different from the relationship of other popular persons to particular brands. Although, as an entrepreneur, Friend constructed a brand and marketed it successfully, he may have also destroyed it - given the recent nature of the scandals, this is yet to be determined. At the very least, he damaged the Anusara Yoga brand image, which illustrates a key dimension of yoga brand image management: the type of yoga one does and what it signifies is not the only thing that determines steps toward consumer lock-in. What one's teacher represents also matters. In other words, yoga brands are often identified with persons as well as styles or values. In this way, yoga entrepreneurs' relationships to their brands are similar to the relationships of other popular persons to particular brands - think of Steve Jobs and the Apple brand. In the same way that Jobs was believed to have abilities beyond mundane marketing skills, Friend was considered to have special insight into the nature of yoga and its path to self-development.

\section{Conclusion}

In the late twentieth century, as economies in urban areas across the world increasingly shifted toward the production and consumption of customized products based on individual consumers' desires and needs, yoga became subject to branding processes. Yoga brands signified the dominant physical and psychological self-developmental desires and needs of contemporary consumers.

Two first-generation yoga entrepreneurs, Iyengar and Muktananda, constructed the early yoga brands: Iyengar Yoga and Siddha Yoga respectively. Iyengar selected from the unbranded yoga system of Krishnamacharya and mass marketed a postural yoga brand that represented physical fitness and wellbeing. Muktananda selected from the unbranded yoga system of his guru, Nityananda, Vedanta, and Kashmir Shaivism, and mass marketed a soteriological yoga brand that provided a remystification of the world and what was perceived as a virtuous guru figure.

Friend, a second-generation yoga entrepreneur, selected from Iyengar Yoga and Siddha Yoga and 
subsequently introduced, elaborated, and fortified the Anusara Yoga brand. By successfully constructing a brand that signified health, the affirmation of life, light-heartedness, and community, he succeeded in the competitive global yoga market, though numerous gaffes in brand image management, involving Friend's transgressions of Anusara Yoga ethical guidelines, threatened the success of his yoga brand.

The cases of Iyengar Yoga, Siddha Yoga, and Anusara Yoga illustrate how yoga brands are saturated with meaning insofar as they signify what consumers deem to be of value. They also illustrate that consumers make choices based on what they consider to be the most unique and accessible path - or brand - to arrive at it.

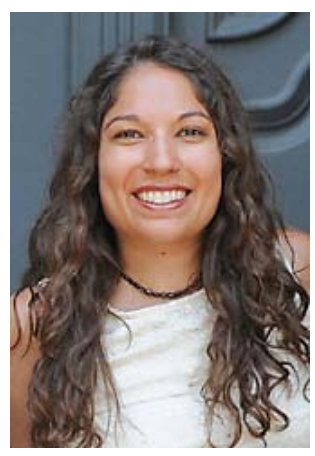

Andrea R. Jain is Assistant Professor of Religious Studies at Indiana University-Purdue University Indianapolis. Her research interests include the history and development of yoga, theories of religion, and religion in relation to the body, especially with regard to sexual and ascetic religious phenomena. More specifically, her research focuses on the transnational construction and global popularization of modern yoga. Her current research projects include a book on the intersections of modern yoga and consumer culture, studies on Christian and Hindu protests against the popularization of yoga, and studies on modern yoga gurus. Email: andrjain(at)iupui.edu

\section{Bibliography}

Albanese, Catherine L. 2007. A Republic of Mind and Spirit: A Cultural History of American Metaphysical Religion. New Haven: Yale University Press.

Alter, Joseph S. 2004. Yoga in Modern India: The Body between Science and Philosophy. Princeton: Princeton University Press.

American Marketing Association 2012. 'Resource Library'. Marketing Power. <http://www.marketingpower. com/_layouts/Dictionary.aspx?dLetter $=B>$ (accessed 5.2.2012)

Anusara, Inc. 2009a. 'About Anusara Philosophy'. Anusara: Yoga, Shri, Community. <http://www.anusara. com/index.php?option $=$ com_content\&view $=$ article\&i $\mathrm{d}=51$ \&Itemid $=85>$ (accessed 7.3.2012).

-2009b. 'Books'. Anusara: Yoga, Shri, Community. $<$ http://www.anusara.com/index.php?option=com virtuemart\&Itemid $=143>$ (accessed 7.3. 2012).

-2009c. 'Ethical Guidelines'. Anusara: Yoga, Shri, Community. <http://www.anusara.com/index. php?option $=$ com_content $\&$ view $=$ article $\&$ id $=71 \&$ Ite $\operatorname{mid}=188>($ accessed 7.3.2012).

-2009d. 'Online Store'. Anusara: Yoga, Shri, Community. $<$ http://www.anusara.com/index.php?option=com virtuemart\&Itemid $=53>($ accessed $7 \cdot 3.2012)$.

Arnould, Eric J. \& Craig J. Thompson 2005. 'Consumer Culture Theory (CCT): Twenty Years of Research'. Journal of Consumer Research 31: 868-9.

Baudrillard, Jean 2002. Jean Baudrillard: Selected Writings. Edited by Mark Poster. Translated by Jacques Mourrain. 2nd edition. Stanford: Stanford University Press.

Billard, Mary 2010a. 'A Yoga Manifesto'. The New York Times, 23.4.2010. <http://www.nytimes. com/2010/04/25/fashion/25yoga.html?ref=homepage $\& s r c=$ me\&pagewanted $=$ print $>($ accessed 23.4.2010 $)$.

-2010b. 'Their Lotus Can't Take Root on a Yoga Mat'. New York Times, 1.10.2010. <http://www. nytimes.com/2010/10/03/fashion/o3noticed. html?_r=1\&emc=eta1\&pagewanted=print $>($ accessed 1.10.2010).

Birney, Bernadette 2012. 'My Resignation Letter'. Bernadette Birney. <http://bernadettebirney.com/2012/02/ my-resignation-letter.html $>$ (accessed 7.3.2012).

Bocock, Robert 1993. Consumption. New York: Routledge. Brooks, Douglas Renfrew, Swami Durgananda, Paul E. Muller-Ortega, William K. Mahony, Constantina Rhodes Bailly \& S. P. Sabharathnam (eds) 1997. Meditation Revolutions: A History and Theology of the Siddha Yoga Lineage. South Fallsburg, New York: Agama Press.

Brooks, Janet Rae 2003. 'Yoga-Supply House Fit for a Market: Utah-built company reflects strength of founder's vision'. The Salt Lake Tribune, 11.5.2003.

Buckner, Julie 2011. 'The Wizard of Wanderlust: John Friend and the Yoga of Recognition'. AOL Healthy Living: Spirit, 10.8.2011. <http://www. huffingtonpost.com/julie-buckner/wanderlustyoga-festival_b_922116.html?view=print\&comm_ ref=false $>($ accessed 7.3.2012).

Caldwell, Sarah 2001. 'The Heart of the Secret: A Personal and Scholarly Encounter with Shakta Tantrism in Siddha Yoga'. Nova Religio: The Journal of Alternative and Emergent Religions 5(1): 9-51.

Carrette, Jeremy \& Richard King 2005. Selling Spirituality: The Silent Takeover of Religion. New York: Routledge.

De Michelis, Elizabeth 2005. A History of Modern Yoga: Patanjali and Western Esotericism. New York: Continuum.

Dobni, Dawn \& George M. Zinkhan 1990. 'In Search of Brand Image: A Foundation Analysis'. Advances in Consumer Research 17: 110-19.

Durgananda, Swami 1997. 'To See the World Full of Saints: The History of Siddha Yoga as a Contemporary Movement'. In: Douglas Renfrew Brooks et al. (eds), Meditation Revolutions: A History and Theology of the Siddha Yoga Lineage; pp. 3-161. South Fallsburg, New York: Agama Press.

Einstein, Mara 2008. Brands of Faith: Marketing Religion in a Commercial Age. New York: Routledge Press. 
Featherstone, Mike 1991. 'The Body in Consumer Culture' In: Mike Featherstone, Mike Hepworth and Bryan S. Turner (eds), The Body: Social Process and Cultural Theory. London: Sage.

-2007. Consumer Culture and Postmodernism. 2nd edition. London: Sage.

Feuerstein, Georg 2003. 'The Lost Teachings of Yoga'. Common Ground, March. <http://www.commonground.ca/iss/0303140/lost_teachings_of_yoga. shtml $>$ (accessed 1.7.2012).

Friend, John 2009a. Anusara Teacher Training Manual. 12th edition. The Woodlands, Texas: Anusara Press.

-2009b. 'John's Blog'. Anusara: Yoga, Shri, Community, 15.8.2009. <https://www.anusara.com/index. php?option $=$ com_wpmu\&m $=200908 \&$ blog_ $\mathrm{id}=2$ \&Itemid $=12>($ accessed 7.3.2012) .

Gennep, Arnold van 1965. The Rites of Passage. London: Routledge \& Kegan Paul.

Giddens, Anthony 1991. Modernity and Self-Identity: Self and Society in the Late Modern Age. Cambridge: Polity Press.

Holt, Douglas B. 2002. 'Why do Brands Cause Trouble? A Dialectical Theory of Consumer Culture and Branding. Journal of Consumer Research 29: 71-2.

ILEA Further and Higher Education Sub-Committee 1968. 'Report submitted on 2 September 1968 by the Education Officer and presented on 10 July 1968'. May/June. London Metropolitan Archives, ILEA/CL/ PRE/16/17.

Iyengar, B. K. S. 1966. Light on Yoga. New York: Schocken. Jain, Andrea R. 2012a. "The Dual-Ideal of the Ascetic and Healthy Body: The Jain Terāpanth and Modern Yoga in the Context of Late Capitalism'. Nova Religio 15(3): 29-50.

-2012b. 'Yoga Guru or CEO? Saving the Brand When Scandal Strikes'. Religion Dispatches, 9.3.2012. <http:// www.religiondispatches.org/archive/culture/5716/ yoga_guru_or_ceo_saving_the_brand_when_scandal_strikes> (accessed 9.3.2012).

-Forthcoming. 'Muktananda: Entrepreneurial Godman, Tantric Hero. In: Ellen Goldberg \& Mark Singleton (eds), Modern Yoga Gurus. New York: Oxford University Press.

Laughing Lotus 2012. Laughing Lotus. <http://www. laughinglotus.com $>$ (accessed 1.1.2012).

Lawrence, Stewart J. 2012. 'The Anusara Yoga Scandal: Can a \$6 Billion Industry Salvage Its Image?' The Huffington Post, 13.2.2012. <http://www.huffingtonpost.com/stewart-j-lawrence/anusara-yogascandal_b_1272471.html> (accessed 7.3.2012).

Leviton, Richard 1990. 'From Sea to Shining Sea'. Yoga Journal (March/April): 57-65.

Lewis, Waylon 2012. 'My Interview with John Friend Regarding jfexposed Accusations'. Elephant Journal (February 8). <http://www.elephantjournal.com/2012/o2/ my-interview-with-john-friend-regarding-ijfexposedi-accusations/> (accessed 7.3. 2012).

Macy, Dayna 2008. 'Practitioner Spending Grows to Nearly \$6 Billion a Year'. Press Release for Yoga
Journal's 2008 Yoga in America Survey. <http://www. yogajournal.com/advertise/press_releases/10> (accessed 26.2.2008).

Mehta, Silva, Mera Mehta \& Shyam Mehta 1990. Yoga: The Iyengar Way. New York: Knopf.

Muktananda, Swami 1985. The Perfect Relationship: The Guru and the Disciple. South Fallsburg, New York: SYDA Foundation.

-1994. Light on the Path. South Fallsburg, New York: SYDA Foundation.

Muller-Ortega, Paul E. 1997. 'Shaktipat: The Initiatory Descent of Power'. In: Douglas Renfrew Brooks et al. (eds), Meditation Revolutions: A History and Theology of the Siddha Yoga Lineage; pp. 407-44. South Fallsburg, New York: Agama Press.

Newcombe, Suzanne 2007. 'Stretching for Health and Well-Being: Yoga and Women in Britain, 1960-1980'. Asian Medicine: Tradition and Modernity 3(1): 37-63.

Park, C. Whan, Bernard J. Jaworski \& Deborah J. MacInnis 1986. Strategic Brand Concept-Image Management'. Journal of Marketing 50(4): 135-45.

Ramamani Iyengar Memorial Yoga Institute 2009a. 'Institutions' B. K. S. Iyengar: The Official Website. <http:// www.bksiyengar.com/modules/Institut/institut.htm> (accessed 5.9.2012).

-2009b. 'Teachers'. B. K. S. Iyengar: The Official Website. <http://www.bksiyengar.com/modules/Teacher/ teacher.asp $>$ (accessed 5.9.2012).

Russell, Cheryl 1993. The Master Trend: How the Baby Boom Generation is Remaking America. New York: Plenum Press.

Samuel, Geoffrey 2008. Origins of Yoga and Tantra: Indic Religions to the Thirteenth Century. Cambridge: Cambridge University Press.

Singleton, Mark 2010. Yoga Body: The Origins of Modern Posture Practice. New York: Oxford University Press.

Sjoman, N. E. 1996. The Yoga Tradition of the Mysore Palace. New Delhi: Abhinav Publications.

Strauss, Sarah 2005. Positioning Yoga: Balancing Acts Across Cultures. New York: Berg.

Swartz, Mimi 2010. 'The Yoga Mogul.' The New York Times, 21.7.2010. <http://www.nytimes.com/2010/07/25/magazine/25Yoga-t. html? pagewanted $=$ print $>$ (accessed 7.3.2012).

SYDA Foundation 2012. 'Centers'. Siddha Yoga. <http:// www.siddhayoga.org/centerslist> (accessed 1.5.2012).

Tomlinson, John 1999. Globalization and Culture. Chicago: The University of Chicago Press.

Turner, Bryan S. 1997. 'The Body in Western Society: Social Theory and its Perspectives'. In: Sarah Coakley (ed.), Religion and the Body. New York: Cambridge University Press.

Turner, Victor 2008. 'Liminality and Communitas.' In: Victor Turner, The Ritual Process: Structure and Anti-Structure; pp. 94-130. New Brunswick: Aldine Transaction Press.

Wanderlust Festival 2011. Wanderlust. <http://www. whistler.wanderlustfestival.com/home $>$ (accessed 1.9.2012). 
White, David Gordon 1996. The Alchemical Body: Siddha Traditions in Medieval India. Chicago: University of Chicago Press.

-1999. 'Tantric Sects and Tantric Sex: The Flow of Secret Tantric Gnosis'. In: Elliot R. Wolfson (ed.), Rending the Veil: Concealment and Secrecy in the History of Religions. New York: Seven Bridges Press.

—2009. Sinister Yogis. Chicago: University of Chicago Press.

-2012. 'Introduction'. In: David Gordon White (ed.), Yoga in Practice. Princeton: Princeton University Press.

Williamson, Lola 2005. 'The Perfectability of Perfection: Siddha Yoga as a Global Movement'. In: Thomas A. Forsthoefel \& Cynthia Ann Humes (eds), Gurus in America. State University of New York Press.

-Forthcoming. 'Stretching toward the Sacred: John Friend and Anusara Yoga'. In: Ellen Goldberg \& Mark Singleton (eds), Modern Yoga Gurus. New York: Oxford University Press.

Willis, Paul 1990. Common Culture. Milton Keynes: Open University Press.

Yoga Dork 2012a. 'Letter from John Friend to Anusara Yoga Teachers'. <http://www.yogadork.com/news/ letter-from-john-friend-to-anusara-yoga-teachers/> (accessed 7.3.2012).

-2012b. 'Running Timeline of Anusara Controversy'. $<$ http://www.yogadork.com/news/running-timelineof-anusara-controversy-updates-and-teacher-resignations/> (accessed 1.9.2012).

-2012c. 'Update: John Friend on Reorganization, Letter from Newly-Appointed Anusara Inc., CEO'. <http:// www.yogadork.com/news/update-john-friend-onreorganization-letter-from-newly-appointed-anusarainc-ceo/> (accessed 7.3.2012).

Yoga to the People 2011a. 'About YTTP: About Us'. Yoga to the People. <http://www.yogatothepeople.com/ about-us/> (accessed 5.1.2012).

-2011b. 'About YTTP: Mantra'. Yoga to the People. <http://www.yogatothepeople.com/about-us/mantra/> (accessed 5.1.2012).

-2011c. 'About YTTP: YTTP Apparel'. Yoga to the People. $<$ http://www.yogatothepeople.com/about-us/yttpapparel/> (accessed 5.1. 2012).

Zauberman, Gal 2003. 'The Intertemporal Dynamics of Consumer Lock-In'. Journal of Consumer Research $30(3): 405-19$. 